\title{
Considerations of luxury wine tourism experiences in the new world: three Waiheke Island vintners
}

\author{
Farzana Zainurin $^{1} \cdot$ Lindsay Neill $^{1} \cdot$ Heike Schänzel ${ }^{1,2}$
}

Received: 31 March 2021 / Accepted: 20 May 2021 / Published online: 14 June 2021

(c) The Author(s), under exclusive licence to Springer Nature Limited 2021

\begin{abstract}
This paper is based on an exploratory study and presents the unique perspectives of three award-winning vintners and their views of luxury wine tourism experiences in an island setting. The luxury segment of the wine industry has experienced steady growth yet understanding of new-world vintner perspectives and motivation for luxury wine production is missing. Strategies used by the vintners include an emphasis on the spiritual dimensions of a vineyard visit, and the maximisation of location, terroir, and scenic views. Key to the strategies was the realisation that customers are first and foremost in the creation of luxury wine tourism experiences.
\end{abstract}

Keywords New world $\cdot$ Luxury wine tourism experiences $\cdot$ Vintner perspectives $\cdot$ Wine production $\cdot$ Exploratory approach $\cdot$ Experiential consumer

\section{Introduction}

This research considers notions of luxury wine production in the New World. Using an explorative, qualitative research design, three award-winning vintners on Waiheke Island were interviewed to solicit their views on luxury wine tourism experiences and how they understood luxury was conveyed to their vineyard guests. Waiheke Island is in the Hauraki Gulf located $21 \mathrm{~km}$ from Auckland's CBD. The island is accessed by a 40-min commuter ferry; however, many vineyard visitors are helicoptered to the island from Auckland city. From relatively recent beginnings (circa 1978), Waiheke Island has become a popular wine/tourist destination. Today, Waiheke Island has approximately 30 boutique wineries (Waiheke Unlimited 2020).

Our research is important because our participants are new-world vintners on vineyards less than 40 years old. Consequently, their views about wine and luxury contrasts those of old-world wine producers with long traditions. Our participants are renowned for their innovative attitudes toward

Heike Schänzel

heike.schanzel@aut.ac.nz

1 Auckland University of Technology, Auckland, New Zealand

2 School of Hospitality \& Tourism, Private Bag 92006, Auckland, New Zealand wine production and wine tourism experiences. In that way, our research offers a unique perspective on luxury wine within a new-world setting on an exclusive island: Waiheke Island and Aotearoa New Zealand.

The paper is structured in the following way. First, we present a brief historical overview of Aotearoa New Zealand's and then Waiheke Island's, wine development. Then, we explore considerations of luxury and present an overview of the luxury-wine tourism-related literature. Next, we explain our explorative, qualitative research approach and present the research findings and their discussion. Finally, the implications of the study, based on the new-world mindsets of the vintner participants, are highlighted in the conclusion.

\section{New Zealand's wine history}

In 1838, and for church use, Bishop Pompallier imported French vine cuttings to New Zealand. In the 1840s, Samuel Marsden introduced viticulture and wine making to help convert Māori to Christianity via the sacrament, and in 1851, the Mission Estate winery was established (Mission Estate 2018). From 1863 to 1880 , New Zealand's viticulture industry flourished. The government quickly introduced licensing for wine sales to control the market. However, despite regulation, some vineyards were established as hobbies. 
Migrant Dalmatians, particularly those in the North Island's gum fields, began to produce wine (Cooper and McDermott 2008).

In 1911, the New Zealand Viticultural Association (Walrond 2015) was established. The Association began to control new wine standards. However, considerations of wine were mixed. Prime Minister of the day, W.F. Massey, had this to say in parliament about "Austrian wine" (a disparaging term for wine produced in New Zealand by Dalmatians):

I have never seen the stuff, but I believe it to be one of the vilest decoctions which can possibly be imagined. ... it is a degrading, demoralising and sometimes maddening drink ... there has been loss of lives attributed ... to the use of Austrian wine as a beverage. (Walrond 2015, p. 4)

Nonetheless, Dalmatian vintners were highly influential in the growth of the nation's wine industry. They exemplified and became the household names of New Zealand wines. Those names include Babich Wines (established 1919); Selak Wines (established 1934); Yukich Wines (now Montana Wines, established 1944); Nobilo Wines (established 1943); and Delegates Wines (established 1947; Walrond 2015).

Dalmatian growers replaced hybrid grapes with single varieties, which resulted in higher quality wines (Walrond 2015) and a booming wine industry in New Zealand. Today, New Zealand's wine industry earns \$1.83bn $(\$ 1.17 \mathrm{bn}$ USD) in exports (Arthur 2019). Local consumption has also increased: in the 1960s, New Zealanders are estimated to have consumed less than half a litre each (Phillips 2016), whereas, by 2018, consumption had increased to $10.9 \mathrm{~L}$ per person (Hutching 2018). Contemporary Aotearoa New Zealand boasts 11 wine regions producing 216,078 tonnes of sauvignon blanc; 27,015 tonnes of chardonnay; 25,763 tonnes of pinot noir; 19,707 tonnes of pinot gris; 9,397 tonnes of merlot; and 4535 tonnes of Riesling grapes (Social Vignerons 2020). While sauvignon blanc from the Marlborough region is the standout performer in terms of export, key to the rise in popularity of visiting vineyards and tasting high-quality wines in New Zealand has been Waiheke Island.

\section{Wine on Waiheke Island}

Kim and Jeanette Goldwater were the first to plant grapes on Waiheke Island in 1978 (Hubble 2014). Their Goldie Estate now covers 30 acres and is renowned for its wine and sustainable viticulture practices (Goldie Estate 2017). Goldie Estate is synonymous with a luxury wine tourism experience and has inspired others. Stephen White, founder of Stonyridge Vineyard, followed in Goldwater's footsteps in 1982. At Stonyridge, he produces new-world wines within Bordeaux blends of cabernet sauvignon, merlot, cabernet franc, malbec, and petit verdot varietals (Stonyridge 2017). Wine has transformed Waiheke Island. Once considered to be an isolated island in the Hauraki Gulf, Waiheke has now become one of New Zealand's most popular vineyard destinations, especially for those seeking a luxury wine tourism experience. Paralleling wine's growth on Waiheke has been its restaurants, promoting a compelling blend of food and wine on the island. However, it is within the narratives of three outstanding and innovative Waiheke vintners that our research is based: Stephen White (Stonyridge Vineyard), Nick Jones (Mudbrick Vineyard), and Paul Dunleavy (Te Motu Vineyard).

\section{Understanding and defining luxury and luxury wine tourism experiences}

The Cambridge online dictionary (2020, n.p.) defines luxury as "a great comfort, especially as provided by expensive and beautiful things" [and a] "condition of abundance or great ease and comfort: sumptuous environment". Luxury also connotes something that is rare, unattainable or often beyond reach and is associated with 'dreaming' and an act of agency; to have what we want but not necessarily need (Turunen 2018).

Luxury, as Kapferer (1998) realised, is the "art applied to functional items [...that] provide extra pleasure and flatter all senses at once" (253). Yet those aesthetic notions are compounded by luxury's association with high price, distinguished quality, scarcity, heritage (Beverland 2005; Dubois et al. 2005; Heine et al. 2014; Vigneron and Johnson 2004), and, more recently, sustainability (Hartmann et al. 2016; Kapferer and Bastien 2012). Additionally, having or experiencing something luxurious bestows feelings of privilege (Thach et al. 2018). In these ways, those authors reflect Heine (2013) observation that luxury is "anything that is desirable and more than necessary and ordinary" (40).

However, concepts of luxury are culturally and sociotemporally located (McNeil and Riello 2016). For example, and within broad generalisation, people from western socio-cultures link luxury with status. Fine dining and its connotations provide exemplars. Contrastingly, people from Eastern socio-cultures perceive luxury within considerations of leisure. For them, leisure includes cruise ship excursions, yachts, luxury spas, and gold (Park and Reisinger 2009). Reflecting luxury's temporality, in France during the 1700-1800s, the classic cafe au lait was a working-class drink that was often consumed in the street (Civitello 2004). Contrasting that, tea was consumed in the drawing rooms of the wealthy (Wallace 2017). 
Yeoman and McMahon-Beattie (2016) stated that with the arrival of mass tourism for the middle classes, the definition of luxury within tourism became diluted and luxury producers needed to redefine luxury as exclusivity. The definition of luxury has shifted to encompass more experiential forms of indulgence, including food and drink experiences on holiday. Increasingly the intensity of the luxury experience is becoming more important for consumers to fulfil their deeper psychic ambitions and confirm their savoir-vivre in the process (Yeoman and McMahon-Beattie 2018, 2019). Luxury-driven tourism experiences are, thus, exemplified by their social value, conspicuousness, and uniqueness with the aim of social emulation, self-esteem, and public display in some way (Correia et al. 2020). However, in the age of COVID-19, luxury could be the experience of living in a COVID-19-free community, such as Waiheke Island. Despite those different constructs of luxury, for many people luxury still holds an association with brand and price, such as impressing friends with the finest wines (Yeoman and McMahon-Beattie 2018). Exemplifying that, a rare bottle of "1945 Chateau Latour will start at [auction at] $\$ 4,000$ but previous sales of [this] sensational red has reached as much as $\$ 9,000$ internationally" (Scoop 2019, para. 2).

According to Thach et al. (2018), research into luxury wine can be traced back to the work of Beverland (2005). Beverland (2005) research within Australian wines revealed that consumers relied on word-of-mouth recommendations in selecting luxury wine purchases. Since then, luxury and luxury wines have become popular research topics (see Table 1). While the literature noted in Table 1 illuminate contemporary luxury wine research, these articles fail to consider luxury from the vintner's perspective. Instead, the notion of marketing and consumer perspectives dominate current literature. The only exceptions are studies by Harlan (2016) and Wolf et al. (2016) who manage to capture some of the Waiheke Island vintners' mindsets. However, the current study extends the meanings of luxury wine production further within the consideration of a 'new-world' terroir.

Thach et al. (2018) characterised luxury wine in seven ways: price; quality; rarity; aesthetics; status; symbolism; and sustainability. Key to those considerations is terroir. ${ }^{1}$ For Thach et al. (2018), a limited terroir ensured that low volumes of luxury wines were produced. Restricted production, consequent to limited land, helped to protect and enhance their seven luxury wine characteristics. In France, an old-world wine producer, terroir is conditioned within the L'Appellation d'origine protegee (Protected designation of

1 Terroir "can be defined as an interactive ecosystem, in a given place, including climate, soil, and the vine rootstock and cultivar" (Science Direct 2021, para. 3) origin, PDO or 'appellation' ${ }^{2}$; Institut National de l'origine et de la qualité 2020). A wine's appellation not only reflects terroir but also traditional methods of wine production. Consequently, consumer knowledge about terroir is enhanced by appellation, and appellation enhances terroir recognition. That relationship, in the case of Champagne and many other French wines, provides a point of French exclusivity. Those considerations underpin notions of wine luxury. Adding to that is France's 'old-world' wine status. Old-world wines are characterised as European. They are produced using traditional viticulture techniques. France's Burgundy region is well known for its production of pinot noir, red wines, and chardonnay-based white wines. Their production can be traced back to the viticultural practices of the monks who established grape cultivation in the region (Tourre et al. 2011).

Contrasting considerations of old-world wines in Europe are new-world wines. New-world wines are those produced in countries outside of the traditional wine-producing areas of Europe and include Aotearoa New Zealand, the United States of America, and Australia. Lacking the wine history of Europe, new-world wines are produced by using innovative grape blends and contemporary viticultural practices. A further category, third-world wines, was proposed by Banks and Overton (2010). In their view, third-world wine producers are characterised not by their use of old-world techniques or new-world processes, but by their rich colonial heritage and long history of wine production, reflecting their "economic and political" positioning (68). Banks and Overton (2010) propose that "Chile, Argentina, Brazil [...] South Africa [... and] Morocco or Lebanon" (p. 68) are third-world wine-producing nations. China is also considered by the authors to be a third-world wine producer because Chinese vintners tend to reject European wine considerations and produce wine to suit Chinese tastes. However, that status is contested by Li et al. (2018), who argued that China is an old-world wine producer because of its ancient history of grape cultivation. According to Li et al. (2018), wine drinking and cultivation in China can be traced to $187 \mathrm{BCE}$. Yet, despite the categorization of wine-producing nations, established considerations of luxury wines are bound within notions of old-world wines and traditional constructs of luxury. This paper seeks to challenge this view by providing insights into the missing understanding of luxury wine tourism experiences from the perspective of new-world vintners using an explorative research approach.

\footnotetext{
2 An appellation is a "legally defined and protected geographical indication used to identify where the grapes for a wine were grown" (Mirriam-Webster 2020, 'Appellation')
} 
Table 1 An overview of luxury wine research 2015-2020

\begin{tabular}{lll}
\hline Author (year) & Theme (location) & Finding
\end{tabular}

Hojman (2015)

Chilean carmenere wine innovations (Chile)

Higgins and Wolf (2015) Millennials as luxury wine buyers (USA)

Harlan (2016)

Stiehler et al. (2016)

Paschen et al. (2016)

Wolf et al. (2016)

Heine et al. (2016)

Cohen et al. (2017)

Thach et al. (2018)

Thach and Olsen (2019)

Sung et al. (2020)
Motivators in luxury wine (USA)

Aesthetics and ephemerality in luxury wine (USA/ Europe)

Aesthetics and ontology in luxury wine (USA/ South Africa)

Icewine and luxury segmentation (Canada)

Motivators in luxury wine consumption (New Zealand)

Authenticity and prestige, lessons from luxury wine

Defining 'luxury', 'premium' and 'fine' wine in China (China)

Wine tensions in Burgundian wines (France)

'Timber-box' effect for premium wines (Australia)
Networking, oenologist experience, foreign ownership, and award status were indicators of innovation; however, research suggests different research approaches will yield different results

Millennials are a growth market in luxury wines

Luxury wine linked to wine knowledge

Magazines and technologies provide wine information for this group

Millennials showed interest in innovative wine packaging

That luxury wine may convey deeper philosophical positions reflecting Voltaire's notions of art and his ongoing philosophical debates with Rousseau

"Luxury is diametrically opposed to good morals" (p. 102)

Luxury wine is purchased for status by novice wine drinkers

The luxury wine consumer recognises wine as an impermanent art form

Classic consumers tended to keep luxury wines

Canada's icewine market is dependent on Chinese tourism

Four consumer categories were identified including "carousers, cabinet collectors, connoisseurs and cellar collectors" (p. 183)

"Luxury wine consumption is rooted in the self-identity of the consumer, whereby, the wine they consume, especially in the presence of their reference or aspirational groups, has to be congruent with the group's perceived norms" (p. 129)

That prestige and authenticity are linked to considerations of luxury

Prestige reflects social standing, authenticity, product quality

The blend of prestige and authenticity allure consumers

These terms hold cynicism in China

'Luxury' being at the top of the quality pyramid, followed by 'premium' and then moving onto 'fine'. A digital expert said, "A 'luxury' tag translates to Chinese consumers as expensive. A 'premium' product is considered to be smaller in quantity and lower in cost. Describing an item as 'fine' is very vague and in Chinese, basically means good" (p. 64)

Conflict within Burgundy's wine producers suggested that they did not agree on precepts of luxury wine and followed different paths in marketing it

Luxury wine linked with food

Luxury wine often purchased for collection (12\%); 53\% consumed wine with friends

Social occasion linked with luxury wine consumption

Wine presented in closed and open-faced wooden boxes gave impressions of luxury to consumers

Consumers were prepared to pay more for wines presented in those ways

Risk (lack of wine knowledge) was mediated by willingness to pay a higher price 
Table 1 (continued)

\begin{tabular}{lll}
\hline Author (year) & Theme (location) & Findings \\
\hline Lembke and Cartier (2020) & $\begin{array}{c}\text { Millennial wine taste differences compared with other } \\
\text { generations (Gen-X, Baby Boomers) (Canada) }\end{array}$ & $\begin{array}{l}\text { Millennials provide the future of wine consumption. } \\
\text { Millennials purchased similar volumes to other genera- } \\
\text { tions and were happy to try new wines. Grape variety, } \\
\text { recommendations, and promotions were less important } \\
\text { to millennials }\end{array}$ \\
& &
\end{tabular}

\section{Methodology}

The choice of methodology was underpinned by the philosophical perspective of interpretivism with the goal of understanding the complex world of lived experience from the point of view of those who live it (Denzin and Lincoln 2000). Through the interpretivist paradigm, smaller samples can be used to generate theories from the results, with both the researcher and the participants involved within the study (Carson 2001). Exploratory studies are conducted when there is insufficient information about a topic (Sarantakos 2005). Additionally, an exploratory study may generate new ideas and opinions about the focus of the research and could help to operationalise important concepts in the research by explaining their structure (Mason et al. 2010). Within this explorative, qualitative research approach, using a combination of semi-structured and unstructured questioning techniques, we interviewed (for around 1 to $2 \mathrm{~h}$ ), audio recorded, and then transcribed interviews with three award-winning Waiheke Island vintners: Stephen White (Stonyridge); Nick Jones (Mudbrick), and Paul Dunleavy (Te Motu). These three vineyards and their vintners produce some of Waiheke's most globally well-known and respected wines. Fieldwork was undertaken between December 2019 and May 2020.

Our focus was to understand the participants' notions of luxury, and how luxury was conveyed to and experienced by their vineyard visitors. Each participant was given a transcription of their interview enabling them to review what they had told us and to make any changes, including additions that they considered to be important. We found this review process benefitted our research by reinforcing our relationship with the participants and opening our findings to wider scrutiny. Using thematic analysis (Braun and Clarke 2006), we then distilled any recurring themes from the checked and amended transcripts. The main themes are presented and discussed in the following section.

\section{Findings and Discussion}

Three metathemes were identified from the participant vintners' considerations of the luxury wine tourism experience:

1. innovation, risk taking, and entrepreneurship;

2. interactions of luxury; and

3. exclusivity.

In this section, the three metathemes are further explained and illustrated with participant quotes. The article then concludes by presenting the implications of the study findings.

\section{Theme 1: innovation/risk taking/entrepreneurship}

Innovation, risk taking, and being entrepreneurial were the most important characteristics that our participants identified in creating and conveying luxury wine experiences for their guests. Innovation, entrepreneurship, and risk taking were initially demonstrated in the decision by each of our three participants to establish vineyards and luxury wine tourist experiences on Waiheke Island. Founding their vineyards required an "ah-ha" moment. Stephen White described the moment that prompted the foundation of his wine estate on Waiheke:

I've been coming here [Waiheke] all my life since I was 5-6 years old. Suddenly it's a penny drop moment that realised for me it's a climate that is hotter and dryer than anywhere else in the country. Therefore, for me, I thought that I could produce great Bourdieu red wines. I began the hunt [for] a piece of north-facing land.

Similarly, Nick Jones' "ah-ha” moment was his realisation of needing to do something out of the ordinary:

the niche market that we took on wasn't viable to have a wine business on Waiheke that would survive just by being a normal wine business. We needed something 
distinctive and constructs of luxury wine were part of that.

In developing his wine business, Nick Jones listened to his intuition and allowed himself to be guided by his personal values. In contrast, Paul Dunleavy aimed to create a luxury wine for the luxury market from the very beginning:

I bought thirty acres on Waiheke, right from the very beginning. I had this specific desire to make a very high-quality wine, and Bordeaux style using traditional French techniques. I had grown up in the wine industry, so I know a little bit about wine. I've met a lot of people.

However, Paul resembled Nick Jones and Stephen White in making judgements intuitively, based on his 'vision' but tempered by his knowledge and advice from industry contacts. Paul felt that his extensive wine experience meant that his intuition could be trusted. His accumulated knowledge of the industry helped him to create 'luxury'. Paul was aware of what constituted a 'good wine' due to his lived experiences, and his entrepreneurial spirit enabled his risk taking.

Thus, while an organic and intuitive approach to wine and creating a vineyard were important considerations, each of our vintners approached the notion of innovation, risk taking, and entrepreneurship differently. For Paul Dunleavey and Stephen White, luxury, via innovation, risk taking, and entrepreneurship, was based on past experiences of terroir. Contrasting that, Nick Jones relied on vision and gut-feeling based upon his own notions of what constituted a luxury wine tourism experience.

Each of our participants did not let the opinions of others stand in the way of achieving their vineyard goals. Reflecting his entrepreneurial innovation and an independent spirit, Stephen said that "everyone thought I was crazy. The banks didn't loan money" [and] "the idea of growing high-quality grapes was unheard of".

Part of being entrepreneurial was the realisation of 'firsts'. As Stephen realised, "we were one of the first in the country to start doing wine tourism to my knowledge" and "the very first to actually to get into this idea of providing a venue". Nick Jones' firsts included their purchase of expensive land that had 'million-dollar views' of Auckland city and the Hauraki Gulf. From that prime real estate, they started small. As Nick recounted, "we started in what is the original restaurant. That was first off, our house. However, when we designed it, we planned for something else; that it could become a winery". Then, "after a while we stripped it out and made it into a restaurant. Then we built a winery on site, that eventually became a cellar tasting room". In that way, the organic growth of Mud Brick reflected the growth of Jones' confidence and business acumen and in his innovative and risk-taking behaviours.

Mud Brick's wine labels provide a case in point. Nick remembered that "we went to like two or three [types of] labelling over the first 10-15 years before we settled on a label and we found something that actually reflected what we felt we were". What they 'were' was located from within: "Robyn [Nick's wife and business partner] actually designed the label we love ya know". But it was not only wine labels that signified luxury for Nick. Nick ensures that he invests back into his luxury customer base. To achieve that, Nick remarked that "change and improvement are vital". Expanding upon that, he continued,

if you come back to Mudbrick after two years, you always gonna see a lot of change and improvement.

Those improvements include new developments, new [garden and vineyard] plantings ... or whatever it may be.

In those ways, Nick engaged constant innovation and entrepreneurial spirit.

Paul Dunleavy was also guided by his intuitive gut-feelings. Paul said, "people thought I was crazy because it took 10 years before I sold a bottle of wine. That was 1987, now I produce something like 100,000 bottles of wine [per season]". Part of that success for Paul was business tracking, particularly his emphasis on bank transactions as a record of business rather that an emphasis on cash. Paul commented, "I don't want cash. I want it to be put in [a] bank account and to give you an invoice. I kinda terminated the vineyards cash market". For Paul, accurate record keeping, facilitated through banking, provided sound knowledge for future innovation and business tracking.

While our participants realised innovation, risk taking and being entrepreneurial in different ways, each was driven by their intuition and their setting aside of the opinions of others. Within that mindset, they created their own 'norm' because they set their goals through their own innovative mindset and convinced themselves that it was the right decision. The vintners then strove to achieve their goals, despite the odds.

\section{Theme 2: interactions of luxury}

Our participants communicated notions of luxury in different ways. For Stephen White, luxury was informed by his judgement and communication skills. Stephen took pride in telling us that he invested time, effort, and emotion in each customer by attempting to not only meet but also exceed their expectations when visiting his vineyard. Part of that interaction was his conscious effort not to judge the people he met. Reflecting that and his intuitive self, Stephen said: 
ahhh essential...essential...Because that visitor may develop an app that becomes a millionaire ya know? And no one should be judged on not having money if that's their choice and their stage of life. And to actually judge someone on that is just stupid and naive. Don't do it. And so, everyone should be welcomed and those options [for judgement] shouldn't be there.

That lack of judgement generated a more holistic way to consider his business. Stephen viewed his vineyard as a spiritual destination and not just a location to grow grapes, harvest, and produce wine. As he succinctly noted, "it is more than just a commercial platform but a place of empowerment". Part of that empowerment is his consideration that constructs of luxury are conveyed to his visitors within the intangible nature of the services his business offers. As Stephen related:

people could actually enjoy the ambience, the way we look at it, the spirituality, the land, regarding this mountain is very spiritual and the valley is spiritual and when [you] drink wine you get the spirits here which is largely empowerment.

Paul also recognised the spiritual connotations of his wine. The process of the wine's 'gestation' is conveyed in a way that adds to its aura of luxury. He said:

It's called élevage ${ }^{3}$...the angel...the bit you give to the angel...the more you age in barrel, the more you give angels. Some people try to slow that down. Mind you we do not hydrate but top it up, we're gonna lose $20 \%$ of [the] original juice. We've had problems - where's it all gone?! Well, the angels have got it!

With this heavenly explanation, Paul promotes a myth that connotes wine luxury: the wine has been touched, if not metaphorically consumed, by angels. That consideration adds an exclusivity — of both production time and considered taste appreciation. Paul's metaphor involving angels (the evaporation of wine) literally concentrates the notion of luxury. Paul also perceived wine as promoting conversation and stories, and as holding the memories imbued in it by its consumers. Consequently, Paul extends his construction of luxury to include the lived experiences of his customers as they drink the wine and how those experiences extend beyond the moment of consumption. Consequently, for Paul,

\footnotetext{
${ }^{3}$ Élevage: "French term for the progression of wine between fermentation and bottling. Comparable to the term'raising' in English; think of élevage as a wine's adolescence or education. The raw fermented juice is shaped during this period into something resembling its final form, through techniques such as barrel aging, filtering and fining. Good winemaking decisions during élevage can help the juice achieve its full potential; bad decisions can leave it flawed." (Wine Spectator 2021, para. 1)
}

notions of luxury wine are co-constructions. Paul provides the venue for the experiences and the tangible product, but then his customers co-create and extend his mythical considerations within their own self-constructed narratives.

Stephen expressed similar views:

Yeah, it's not just social. Social is just like pouring wine. This so actually more like special occasions and we get together and drink that wine or we'll celebrate your degree, and we'll open a bottle of wine or your birthday, or wedding anniversary. So, it becomes a wine of symbolic nature celebrating a certain event.

Additionally, Stephen realised commonality: that the notion of luxury wine attracted people who considered luxury to be important. He commented:

there is a strategic brand association. So, we are if you like a lot of good things, you'll like our wines and it's the recreation activities of the rich that are totally in alignment with drinking high-quality wine.

For Nick Jones at Mud Brick, luxury was constructed and experienced over time. Even his vineyard name (Mud Brick) connoted, for him, how something ordinary could become not only desirous but also associated with luxury. In that way, Nick associated the ordinary with the extraordinary. Nick transferred that thinking to his vineyard environment, in that, rather than reflecting European sensibilities, Nick and Robyn created an aesthetic of 'New Zealand-ness'.

\section{Theme 3: exclusivity}

Having an exclusive venue was important to all three participants. In addition, each of our vintners considered that word of mouth was the much-preferred way to market a luxury wine tourism experience. Nick, Paul, and Stephen did not want to aggressively advertise their businesses. Rather, they considered that word of mouth not only helped them to convey exclusivity, but that it, in turn, connoted luxury. Best exemplifying that was Paul. He commented that his visitors came "via word of mouth". Communicating with those visitors at the vineyard Paul added "you can make connections with people like that they will tell other people about us".

Producing the wine without any compromise was vitally important to creating luxury. As Paul commented:

do it right or go home. Wine is a living product...all the way...once it's used up all the sulphur that's it, its gonna turn into vinegar. If you put too much in, it affects the colour and flavour...if you wanna make for the luxury market you've got to master all of these 
stuff...no compromise...if you need to extend the mortgage you do it...simple.

Stephen also only produced luxury wines that were worthy of his vineyards label. As he noted, "we use declassification $^{4}$ to maintain the high-quality stuff so if it's got this label on it it's going to be bloody good". For Nick, creating quality wine experiences meant focussing on his vineyard services. Nick's emphasis on New Zealand-ness incorporated the Kiwi propensity for being 'laid back'. As he revealed,

a luxury wine experience is about people. It's not just looking at something that is really nice ... I think our style is much more relaxed, welcoming, open in comparison to [a] Bordeaux style of service which is very formal.

In Nick's view, a luxury wine experience could be enjoyed on a bean bag that was strategically placed in the vineyard gardens to maximise the Hauraki Gulf and city views. Yet there was a fine line in creating a laid-back luxury wine tourism experience involving the relationship between informality and exclusivity. As Nick wryly commented, "you need a nice balance between keeping up luxury and not catering to a mass market. As a vineyard visitor, you don't want turn up to a place and see tourist buses pouring in there and all that".

Common to all our participants, was that wine luxury involved exclusivity. They all emphasised that luxury wine included experiences that were bespoke and that were situations within which vineyard visitors could create their own memories and narratives. These exclusive narratives, in turn, would act as vineyard advertising via word of mouth.

\section{Discussion}

Key to our vintners' understanding and conveyance of luxury were their mindsets. Their distinctive ways of thinking reinforced their status as new-world wine makers because they were realising luxury in new ways. Those new ways included the co-creation of experience, a holistic view of experiences involving wine, and their own entrepreneurial spirit in ensuring that their customers' vineyard experiences were unique. Egalitarianism was an additional, important mindset component for one participant. For him, a customer's inability to afford exclusivity was perhaps only temporary, and no customer was considered in disrespectful ways as people's financial circumstances are subject to change. That realisation of potential future co-creation possibilities

\footnotetext{
${ }^{4}$ Declassification of wine means that a producer sets aside a certain portion of the wine, label it without vineyard name or appellation, and sell that high-quality wine for below market value. In other words, they 'declassify' the wine (WINC 2021).
}

reflects Wolf et al. (2016) understanding that "luxury wine consumption is rooted in the self-identity of the consumer, whereby, the wine they consume, especially in the presence of their reference or aspirational groups, has to be congruent with the group's perceived norms" (129). Additionally, the co-creation of experience emphasised by the Waiheke vintners reinforces Heine et al. (2016) and Yeoman and McMahon-Beatte $(2016,2018)$ conclusions that prestige, local culture, enrichment, and authenticity of experience are key considerations in generating luxury tourism experiences.

Consequently, our participants used luxury wine in transcendent ways, allowing the wine and its consumption environment to facilitate memories and positivity for their customers. Those qualities reflect Harlan (2016) suggestion that the enjoyment of wine holds deeper philosophical roots, as well as Thach and Olsen (2019) connecting of wine consumption and social occasion. In those ways, our participants were characterised by their independent spirit of innovation, change, risk taking, and entrepreneurial mindset, something paralleled by Thach et al. (2018) Burgundy wine research. However, our vintners did not totally subscribe to Thach et al. (2018) seven luxury wine characteristics. Of those characteristics, price and rarity held lesser importance than high quality, aesthetics, status, symbolism, and sustainability. Our vintners recognised how interaction and hospitable behaviours added to a luxury tourism experience in the minds of their customers. Yet key to those considerations was terroir. Waiheke's island location meant that vineyard visitors were committed to their vineyard visits due its unique reputation and lack of easy access by car. That commitment added clout to their perceptions of luxury wine experiences and opens a future domain for ongoing research.

\section{Conclusions}

Based on a scoping review of extant literature on luxury wine, it is evident that while there is a rich stream of research in luxury branding and consumption, relatively little research has been done on luxury wine consumption (Wolf et al. 2016) as a tourism experience. Even less is known about luxury wine production, and the perspectives of new-world vintners are particularly absent from research. Our research explored how luxury was created and then delivered to vineyard guests by three award-winning newworld vintners. We found that a new-world mindset emphasising innovation, risk taking, entrepreneurship, luxurious interaction, and exclusivity were seminal concepts for our vintner participants. These new-world wine producers were not bound by the traditions and formality of their old-world counterparts. Rather, our participant vintners embraced constant change within the experience they offered, alongside 
consistency in the quality of their product, as the cornerstones of their constructs of consumer luxury wine tourism experiences. Our participants opened their vineyard experiences for their customers to co-create their own memories and meanings, including vital aspects of terroir and spiritual dimensions, elevating the luxury wine tourism experience to a new level. This finding broadens the understanding of a luxury wine tourism experience to include much more than the wine itself by instilling a new-world mindset.

This exploratory study highlights some interesting aspects of luxury wine production in a new-world country and raises important questions that can be addressed in future studies. Further studies should consider developing a luxury wine producer typology beyond boutique vineyards and comparisons with other new-world countries. An investigation into the interplay between the constructs identified in this paper will certainly advance theoretical and practical knowledge in relation to this fascinating phenomenon, where luxury wine production appears elusive but with much appeal to future understandings of the new experiential consumer in tourism.

\section{References}

Arthur, R. 2019. New Zealand's wine industry celebrates its 200th anniversary, 17 September. https://www.beveragedaily.com/artic le/2019/09/17/new-zealand-s-wine-industry-celebrates-its-200thanniversary. Accessed 28 Dec 2020.

Banks, G., and J. Overton. 2010. Old world, new world, third world? Reconceptualising the worlds of wine. Journal of Wine Research 21 (1): 57-75.

Beverland, M.B. 2005. Crafting brand authenticity: The case of luxury wines. International Journal of Management Studies 42 (5): $1003-1029$.

Braun, V., and V. Clarke. 2006. Using thematic analysis in psychology. Qualitative Research in Psychology 3 (2): 77-101.

Cambridge Online Dictionary. 2020. Luxury. https://dictionary.cambr idge.org/dictionary/english/luxury. Accessed 30 Dec 2020.

Carson, D. 2001. Qualitative Marketing Research. London: Sage.

Civitello, L. 2004. Cuisine and culture: A history of food \& people. Hoboken, NJ: Wiley.

Cohen, J., A. Corsi, L. Lockshin, J. Bruwer, and R. Lee. 2017. What do 'luxury', 'premium' and 'fine' wine mean in China? Wine \& Viticulture Journal 32 (3): 63-54.

Cooper, M. and J. McDermott. 2008. Wine atlas of New Zealand, 2nd edn., Hodder Moa, Auckland.

Correia, A., M. Kozak, and G. Del Chiappa. 2020. Examining the meaning of luxury in tourism: A mixed-method approach. $\mathrm{Cur}$ rent Issues in Tourism 23 (8): 952-970.

Denzin, N.K. and Y.S. Lincoln (eds). 2000. Handbook of qualitative research. 2nd edn., Sage, Thousand Oaks, CA.

Dubois, B., S. Czellar, and G. Laurent. 2005. Consumer segments based on attitudes toward luxury: Empirical evidence from twenty countries. Marketing Letters 16 (2): 115-128.

Goldie Estate 2017. Champion trophy at Royal Easter Show, 24 April. http://goldieestate.co.nz/news-1/champion-trophy-at-royal-eastershow/. Accessed 28 Dec 2020.

Harlan, H. 2016. The aesthetics and ephemerality of luxury wine. International Journal of Wine Business Research 28 (2): 102-104.
Hartmann, L.H., S. Nitzko, and A. Spiller. 2016. The significance of definitional dimensions of luxury food. British Food Journal 118 (8): 1976-1998

Heine, K. 2013. The concept of luxury brands (taxonomy \& definition). white paper. http://www.conceptofluxurybrands.com/content/ 20121107_Heine_The-Conceptof-Luxury-Brands.pdf. Accessed 30 Dec 2020.

Heine, K., G. Atwal, and Z. Ates. 2014. Luxury wine marketing, 235246. Paris: Wine Business Management. Pearson.

Heine, K., M. Phan, and G. Atwal. 2016. Authenticity and prestige: What luxury brands could learn from the wine industry. Journal of Luxury Research 1 (2): 177-190.

Higgins, L., and M. Wolf. 2015. Millennials as luxury wine buyers in the United States? International Journal of Wine Business Research 28 (3): 190-205.

Hojman, D. 2015. Radical innovation in luxury carmenere wine from Chile. Journal of Wine Research 26 (1): 40-63.

Hubble, G. 2014. Waiheke Island wine region. https://www.wineguy. co.nz/index.php/glossary-articles-hidden/606-waiheke-islandwine-region. Accessed 30 Dec 2020.

Hutching, C. 2018. Falling consumption among young people will affect industry warns wine writer Michael Cooper. Stuff, 15 November. https://www.stuff.co.nz/business/108620887/fallingconsumption-among-young-people-will-affect-industry-warnswine-writer-micheal-cooper. Accessed 30 Dec 2020.

Institut National de l'origine et de la qualité 2020. L'Appellation d'origine protégée [Protected designation of origin]. https://www. inao.gouv.fr/eng/Official-signs-identifying-quality-and-origin/ PDO-AOC. Accessed 31 Dec 2020.

Kapferer, J.N. 1998. Why are we seduced by luxury brands? Journal of Brand Management 6 (1): 44-49.

Kapferer, J.N., and V. Bastien. 2012. The luxury strategy: Break the rules of marketing to build luxury brands. London: Kogan Page Publishers.

Lembke, S., and L. Cartier. 2020. Wine consumers in British Columbia, Canada: Towards understanding how Millennials differ from previous generations. International Journal of Wine Business Research 32 (3): 441-455.

Li, H., H. Wang, H. Li, S. Goodman, P. van der Lee, Z. Xu, A. Fortunato, and P. Yang. 2018. The worlds of wine: Old, new and ancient. Wine Economics and Policy 7 (2): 178-182.

Mason, P., M. Augustyn, and A. Seakhoa-King. 2010. Exploratory study in tourism: Designing an initial, qualitative phase of sequenced, mixed methods research. International Journal of Tourism Research 12 (5): 432-448.

McNeil, P., and G. Riello. 2016. Luxury: A rich history. New York, NY: Oxford University Press.

Mirriam-Webster. 2020. Appellation. https://www.merriam-webster. com/dictionary/appellation. Accessed 28 Dec 2020.

Mission Estate. 2018. Our story. https://missionestate.co.nz/missionestate-winery-the-birthplace-of-nz-wine/. Accessed 31 Dec 2020.

Park, K., and Y. Reisinger. 2009. Cultural differences in shopping for luxury goods: Western, Asian and Hispanic tourists. Journal of Travel \& Tourism Marketing 26 (8): 762-777.

Paschen, J., U. Paschen, and J. Kietzmann. 2016. A votre sante-Conceptualising the AO typology for luxury wine and spirits. International Journal of Wine Business Research 28 (2): 170-186.

Phillips, J. 2016. Alcohol: the drink revolution, 1960 onwards. Te Ara: The Encyclopedia of New Zealand. http://www.TeAra.govt.nz/en/ alcohol/page-4. Accessed 30 Dec 2020.

Sarantakos, S. 2005. Social research, 3rd ed. Basingstoke: Palgrave Macmillan.

Science Direct. 2021. Terroir. https://www.sciencedirect.com/topics/ agricultural-and-biological-sciences/terroir. Accessed 4 Jan 2021.

Scoop. 2019. 74-year-old bottle of wine going to auction, 5 March. https://www.scoop.co.nz/stories/BU1903/S00091/ 
74-year-old-bottle-of-wine-going-toauction.htm. Accessed 2 Jan 2021

Social Vignerons. 2020. Total volume of grapes produced 2015. https:// i0.wp.com/socialvignerons.com/wp-content/uploads/2015/10/ New-Zealand-grape-veriety-wine-production-region-VintageIndicators-2015_Page_1_2_small.jpg. Accessed 30 Dec 2020.

Stiehler, B., A. Caruana, and J. Vella. 2016. Using an aesthetics and ontology framework to investigate consumers' attitudes toward luxury wine brands as product category: Evidence from two countries. International Journal of Management Studies 28 (2): 154-169.

Stonyridge. 2017. About us. https://www.stonyridge.com/about-us/. Accessed 30 Dec 2020

Sung, B., Crawford, R., Teah, M., Stankovic, M. and Phau, I. 2020. The 'timber box' effect for premium wines. Journal of Retailing and Consumer Services 54.

Thach, L., S. Charters, and L. Cogan-Marie. 2018. Core tensions in luxury wine marketing: The case of Burgundian wineries. International Journal of Wine Business Research 30 (3): 343-365.

Thach, L., and J. Olsen. 2019. Luxury wine: Analysing motivations of luxury wine buyers in the US market. Apstract 13 (3-4): 51-58.

Tourre, Y.M., D. Rousseau, L. Jarlan, E.L.R. Ladurie, and V. Daux. 2011. Western European climate, and Pinot noir grape harvest dates in Burgundy, France, since the 17th century. Climate Research 46 (3): 243-253.

Turunen, L.L.M. 2018. Interpretations of luxury: Exploring the consumer perspective. Berlin: Springer.

Vigneron, F., and L.W. Johnson. 2004. Measuring perceptions of brand luxury. The Journal of Brand Management 11 (6): 484-506.

Waiheke Unlimited. 2020. Waiheke Island. https://www.waihekeunl imited.co.nz/waiheke/vineyards/. Accessed 3 Jan 2021

Wallace, M. 2017. Greater Gotham: A history of New York city from 1898 to 1919. New York: Oxford University Press.

Walrond, C. 2015. "Dalmatians". Te Ara - the Encyclopedia of New Zealand. http://www.TeAra.govt.nz/en/dalmatians. Accessed 2 Feb 2021.

WINC. 2021. What are declassified wines? https://www.winc.com/ blog/what-are-declassified-wines. Accessed 24 Feb 2021
Wine Spectator. 2021. Elevage. https://www.winespectator.com/gloss ary/index/word/elevage. Accessed 4 Jan 2021.

Wolf, H., S. Morrish, and J. Fountain. 2016. A conceptualisation of the perceptions and motivators driving luxury wine consumption. International Journal of Wine Business Research 28 (2): 120-133.

Yeoman, I., and U. McMahon-Beattie. 2016. The future of food tourism. Journal of Tourism Futures 2 (1): 95-98.

Yeoman, I., and U. McMahon-Beattie. 2018. The future of luxury: Mega drivers, new faces and scenarios. Journal of Revenue and Pricing Management 17 (4): 204-217.

Yeoman, I.S., and U. McMahon-Beattie. 2019. The experience economy: Micro trends. Journal of Tourism Futures 5 (2): 114-119.

Publisher's Note Springer Nature remains neutral with regard to jurisdictional claims in published maps and institutional affiliations.

Farzana Zainurin is completing a Master of Gastronomy degree at Auckland University of Technology, New Zealand. As a migrant student, Farzana is fascinated by Aotearoa New Zealand's food and beverage culture. Her research within New Zealand's luxury wine industry has not only enhanced her gastronomic knowledge but also facilitated her first academic publication.

Lindsay Neill is a senior lecturer in hospitality management at Auckland University of Technology, New Zealand. Lindsay holds research interests in vernacular culture, food, identity, and popular culture. Lindsay has an extensive publishing portfolio including the co-authorship of the award-winning text The New Zealand Chef and The Great New Zealand Pie Cart.

Heike Schänzel is an associate professor in international tourism management at Auckland University of Technology, New Zealand. Her research interests include families, children, gender, experiential dimensions, and well-being in tourism. She is passionate about better understanding family fun along with the facilitation of sociality and meaningful experiences within the context of tourism. 